\title{
Namibit a doprovodná mineralizace fluoritové žíly Nadějná u Kotliny v Krušných horách (Česká republika)
}

\author{
Namibite and accompanying mineralization of fluorite vein Nadějná near Kotlina \\ in the Krušné hory Mts. (Czech Republic)
}

\author{
Petr Pauliš ${ }^{1,2) *}$, Roman GrambličKa ${ }^{3)}$, Luboš VrtišKa ${ }^{2)}$, Zdeněk Dolní̌́eK ${ }^{2)}$, OndŘej Pour ${ }^{4)}$,

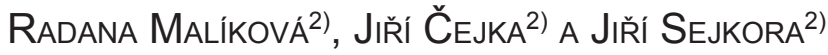

1)Smíškova 564, 28401 Kutná Hora; *e-mail: petr.paulis@post.cz

${ }^{2)}$ Národní muzeum, Cirkusová 1740, 19300 Praha 9 - Horní Počernice

3) Severočeské doly a.s., ul. 5. května 213, 41829 Bílina

4)Česká geologická služba, Geologická 6, 15200 Praha 5

Pauliš P, Gramblička R, VRtiška L, Dolniček Z, Pour O, Malíková R, Čejka J, Sejkora J (2020) Namibit a doprovodná mineralizace fluoritové žily Nadějná u Kotliny v Krušných horách (Česká republika). Bull Mineral Petrolog 28(1): 170178 ISSN 2570-7337

\begin{abstract}
Supergene Bi mineralization with namibite, bismutoferrite and bismutite was found on a quartz-fluorite vein Nadějná near the Kotlina in the Krušné hory Mts. (Czech Republic). Namibite forms green coatings on the cracks of fluorite vein and more rarely dark green glassy lustrous, hedgehog-shaped aggregates up to $0.2 \mathrm{~mm}$ in size formed by flat needlelike crystals. The unit-cell parameters of namibite refined from the powder X-ray data are: a 6.2096(18), $b$ 7.395(2), c 7.4708(18) $\AA$, a 90.1(2) ${ }^{\circ}, \beta 108.73(15)^{\circ}, y \quad 107.45(19)^{\circ}$ and $V 308.09(15) \AA^{3}$. Its chemical analyses correspond to the empirical formula $\left(\mathrm{Cu}_{0.93} \mathrm{Fe}_{0.03} \mathrm{Ca}_{0.01}\right)_{\Sigma 0.97}(\mathrm{BiO})_{1.79}\left(\mathrm{~V}_{0.97} \mathrm{P}_{0.02} \mathrm{Cr}_{0.01}\right)_{\Sigma 1.00} \mathrm{O}_{4}(\mathrm{OH})_{0.75}$. Bismutoferrite forms yellow powdery aggregates in cracks and in small cavities of fluorite. Its chemical analyses correspond to the empirical formula $\left(\mathrm{Fe}_{1.91}\right.$ $\left.\mathrm{Cu}_{0.03} \mathrm{Mg}_{0.02} \mathrm{Al}_{0.02} \mathrm{Ca}_{0.01}\right)_{\Sigma 1.99} \mathrm{Bi}_{0.92}\left(\mathrm{SiO}_{4}\right)_{2.00}(\mathrm{OH})_{0.68}$. Bismutite forms yellow-white pseudomorphoses probably after the acicular crystals of primary $\mathrm{Bi}$ sulfide (emplectite or bismuthinite) up to $2 \mathrm{~mm}$ long in the fluorite vein. Study of Raman spectra was performed for all studied minerals.
\end{abstract}

Key words: namibite, bismutoferrite, bismutite, powder X-ray diffraction data, unit-cell parameters, chemical composition, Raman spectroscopy, fluorite vein Nadějná, Kotlina, Krušné hory Mts., Czech Republic

Obdrženo 4. 5. 2020; prijjato 5. 6. 2020

\section{Úvod}

Na základě potřeb československého průmyslu byl v letech 1963 - 1970 proveden vyhledávací průzkum fluoritových a barytových surovin ve střední části Krušných hor, která byla shledána za území nejbohatší na známé fluorit-barytové indicie a současně nejperspektivnější z celých Krušných hor (Mayerová, Mayer 1967; Lienert 1971). V rámci těchto průzkumných prací byla ověřována raada indicií a zjištěných výchozů žil. Jednou z nich byla i fluoritová žíla Nadějná (pojmenována pracovníky GP), která se nachází v lesním terénu cca $1 \mathrm{~km}$ v. od železniční stanice Měděnec, $1 \mathrm{~km}$ jv. od malé obce Kotliny (dnes část Měděnce) a $5 \mathrm{~km}$ sz. od Klášterce nad Ohří (GPS: $50^{\circ} 25^{\prime} 44.801$ “'N, $13^{\circ} 8 ` 40.274$ “E; obr. 1). Tato fluoritová žíla byla znovuobjevena a otevřena druhým z autorů této publikace (RG), který popisovaný materiál $s$ namibitem a doprovodnou Bi mineralizací objevil. $\mathrm{V}$ roce 2019 byly v širším okolí lokality zahájeny intenzivní lesnické práce včetně přeorání svrchní vrstvy půdy, při kterých byla zdevastována zhruba polovina délky pinkového tahu, včetně popisovaného výskytu se supergenní Bi mineralizací. $V$ současnosti jsou tak možnosti sběru na této lokalitě zcela mizivé.

\section{Geologická situace}

Na tuto fluoritovou žílu poprvé upozornil Chrt (1962), který ji charakterizoval (chybně) jako žílu fluorit-barytového typu Hradiště a lokalizoval ji sv. od dnes zaniklé obce Venkov. Na žíle byl v minulosti, jak dokazuje rada pinek a štola, těžen v nevelkém množství fluorit (pravděpodobně pro blízké železárny), prípadně i limonitické Fe rudy. Povrchové dobývky jsou ukloněny $\mathrm{k} J \mathrm{~J}$ a jejich současná hloubka dosahuje $3 \mathrm{~m}$. Od SZ byla žíla nafárána starou, dnes zavalenou štolou neznámého stáří. $V$ registru důlních děl a poddolování ČGS-Geofondu je toto staré dílo (cca $40 \mathrm{~m}$ dlouhá štola), které se nachází na katastru obce Kotlina, vedeno pod číslem 2934. V rámci průzkumných prací ze šedesátých let minulého století byla žíla sledována ve stejném rozsahu, $v$ jakém ji sledovaly pinky starců, tj. v délce cca $210 \mathrm{~m}$. Severozápadní omezení žíly je tektonické, poruchou směru $Z$ - $V$ se sklonem $77^{\circ} \mathrm{k} \mathrm{J}$, v níž byla vyražena stará štola. Na JV fluoritová výplň vyznívá (Mayerová, Mayer 1967).

Žíla je uložená $v$ detailně provrásněných, středně zrnitých rozpadavých neoproterozoických svorových rulách, které jsou součástí krušnohorského krystalinika. Tyto slídnaté ruly mají šedou barvu, na plochách břidlič- 


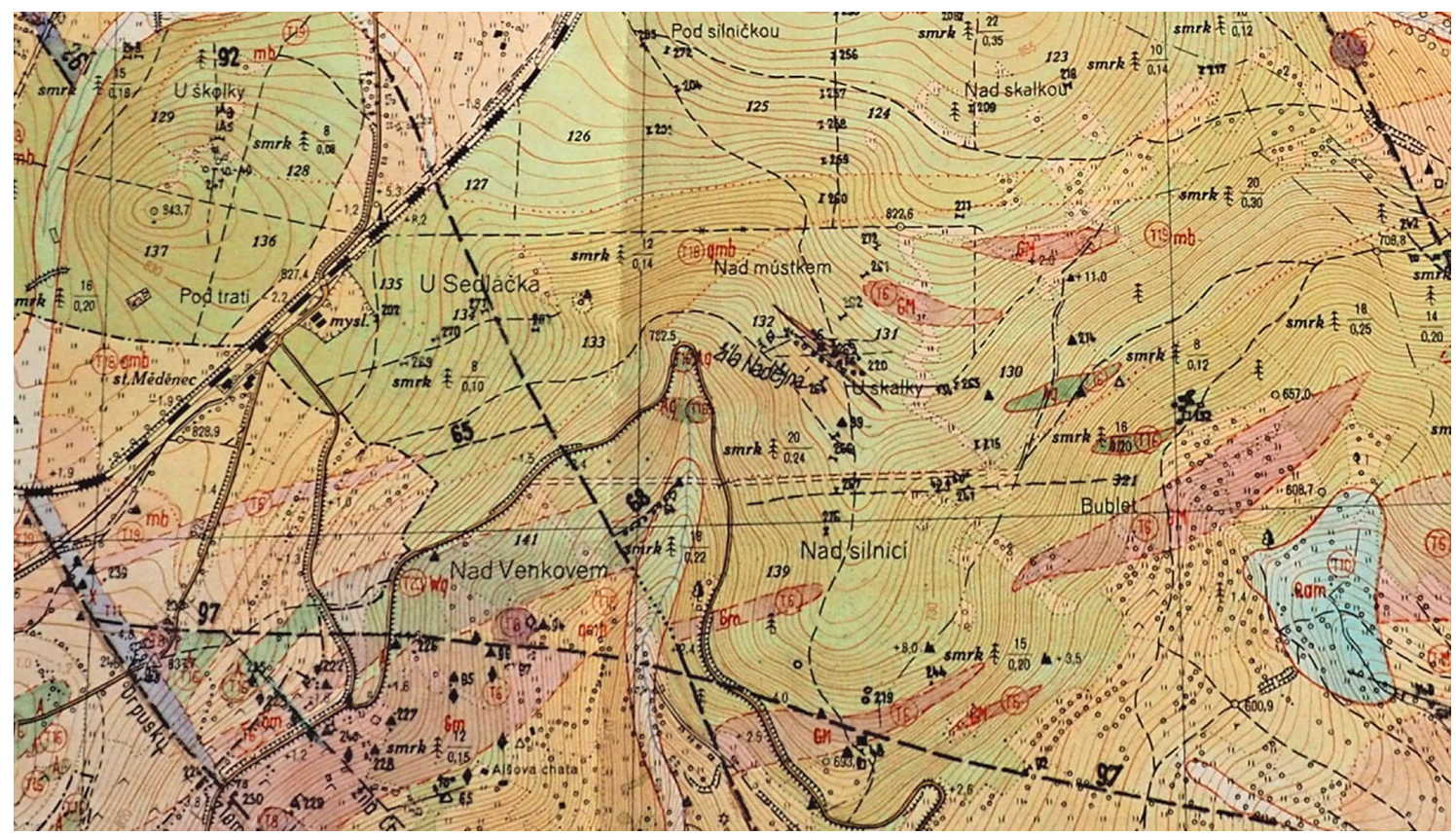

Obr. 1 Poloha žily Nadějná na geologické mapě (Mayerová, Mayer 1967).

natosti mají černohnědé povlaky Fe a Mn hydroxidů a jsou proniklé nepravidelnými žilkami křemene do mocnosti $5 \mathrm{~mm}$. Při kontaktu se žílou jsou ruly výrazně alterované a částečně mylonitizované, proniklé tmavě rudohnědým křemenem. Žíla má směr asi $130^{\circ}$, sklon $65^{\circ} \mathrm{k} \mathrm{JZ}$, čočkovitý charakter a asymetrický vývoj. Žíla Nadějná představuje vícefázovou výplň $0.3-1.3 \mathrm{~m}$ mocné poruchové zóny, složené ze starších $2-15 \mathrm{~cm}$ mocných proniků křemenných žil s príměsí fluoritu a hematitového pigmentu. Střed žilné zóny tvoří velmi čistý $10-35$ cm mocný fluorit žlutozelené a nafialovělé barvy. Fluoritové polohy mají často brekciovitý charakter; fluorit bývá podrcený či zvětralý na detrit o velikosti zrna do $2 \mathrm{~cm}$. Žíla je často porušována a posunována tektonickými liniemi převážně $V-Z$ směru. Výplň tvoří bělavý jíl. Provedený mineralogický výzkum prokázal, že výplň žíly je tvořena několika generacemi křemene a fluoritu, $v$ malé míre $\mathrm{Fe}$ hydroxidy. Nejstarší křemen I, impregnující horninu, je šedorůžový, křemen II je bílý až šedobílý, brekciovitý, pokrytý tenkou (0.5 $\mathrm{mm}$ ) vrstvou opálu. Hematitový křemen III červené až červenohnědé barvy zpevňuje žilnou výplň. Nejmladší křemen IV tvoří čirou drúzovou výplň dutin. Fluorit byl zjištěn ve třech generacích. Nejstarší je křišt'álově čirý, tvořící až $1 \mathrm{~cm}$ velké krychlové krystaly, někdy se zonární strukturou. Tyto krystaly či jejich fragmenty uzavírá mladší hrubozrnný zelenohnědý fluorit a nejmladší jemnozrnný bělavý fluorit (Chrt 1973). Poměrně často se $v$ křemenných partiích objevují negativy po krychlových krystalech fluoritu dosahující velikosti $15 \mathrm{~mm}$. V blízkosti žíly byly při báňských pracích nalezeny $v$ suti tři balvany zelenožlutého fluoritu s ojedinělými fialovými krystaly fluoritu s křemenem. Obsahy $\mathrm{BaSO}_{4}$

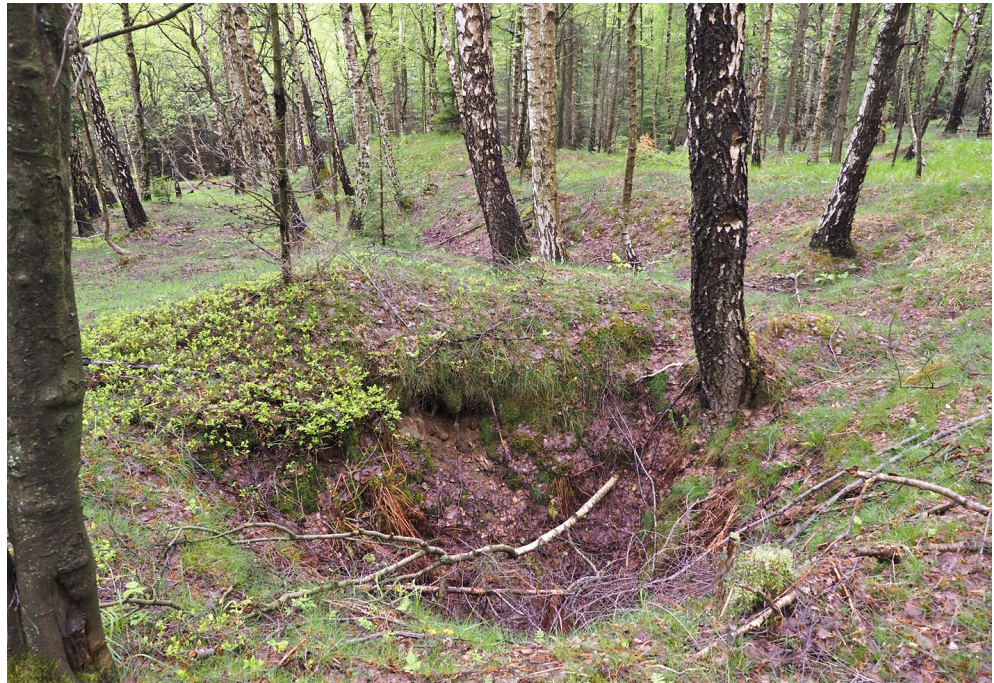

Obr. 2 Pásmo starých pinek na žíle Nadějná u Kotliny, foto P. Pauliš (2019).

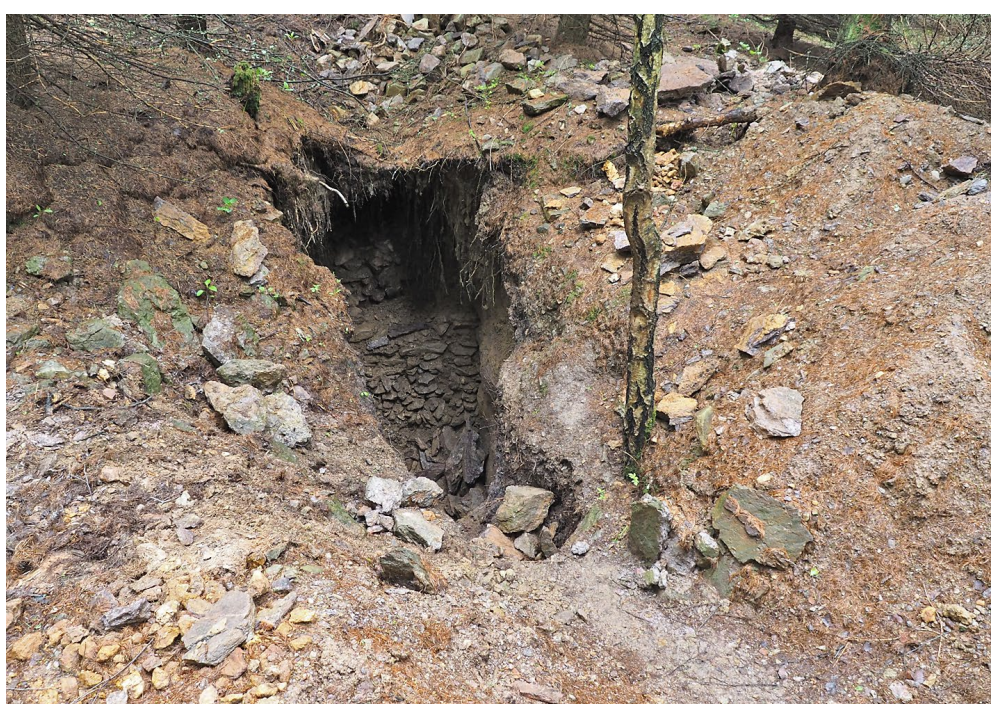

Obr. 3 Vykopaná sonda na pásmu starých pinek na žile Nadějná u Kotliny, foto P. Pauliš (2019). 
dosahovaly maximálně $19 \%$, makroskopicky ani mikroskopicky však nebyl zjištěn. Na rozdíl od blízkého ložiska Hradiště nebyl zjištěn ani pyrit (Mayerová, Mayer 1967).

\section{Metodika výzkumu}

Rentgenová difrakční data namibitu byla získána pomocí práškového difraktometru Bruker D8 Advance (Národní muzeum, Praha) s polovodičovým pozičně citlivým detektorem LynxEye za užití CuKa záření (40kV, $40 \mathrm{~mA}$ ). Práškový preparát byl nanesen $v$ acetonové suspenzi na nosič zhotovené z monokrystalu křemíku a následně pak byla pořízena difrakční data ve step-scanning režimu (krok $0.01^{\circ}$, načítací čas $8 \mathrm{~s} / \mathrm{krok}$ detektoru, celkový čas experimentu cca 15 hodin). Pozice jednotli-

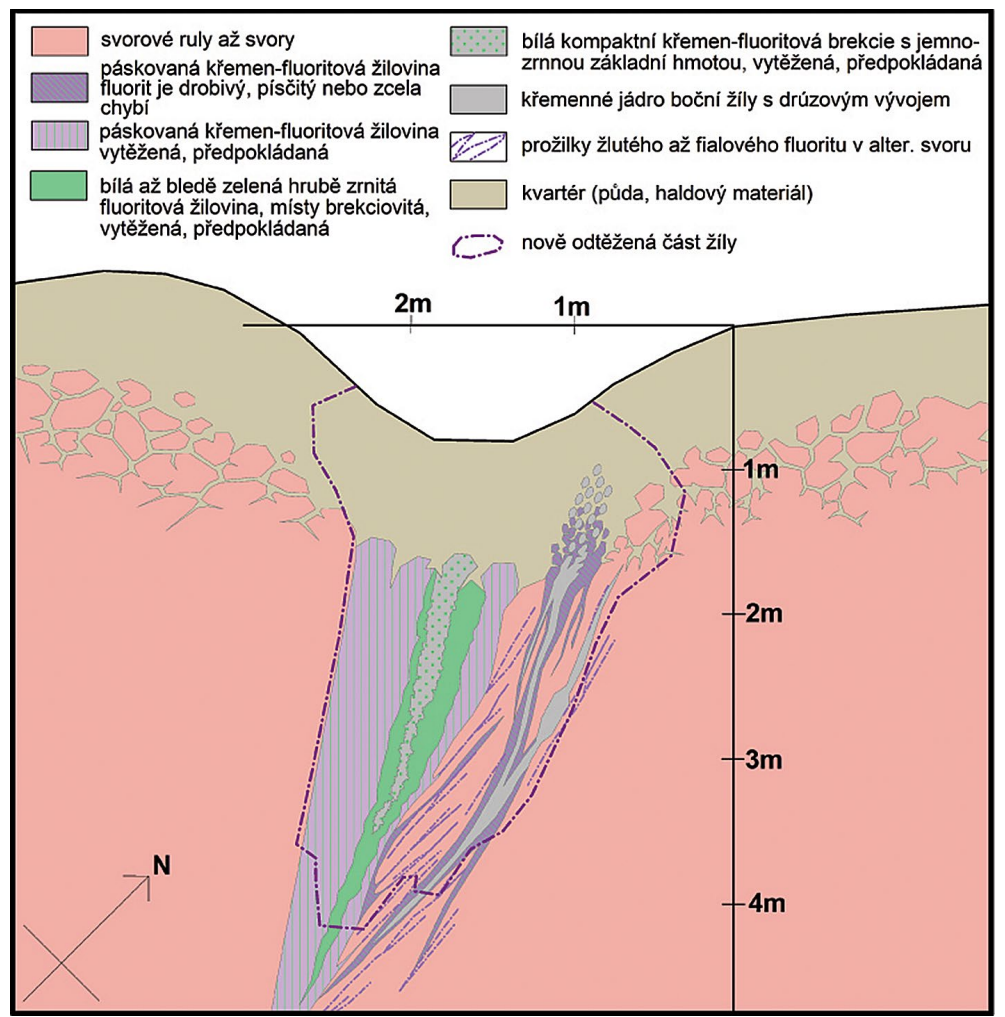

Obr. 4 Profil žíly Nadějná v místě sondy (kreslil R. Gramblička).

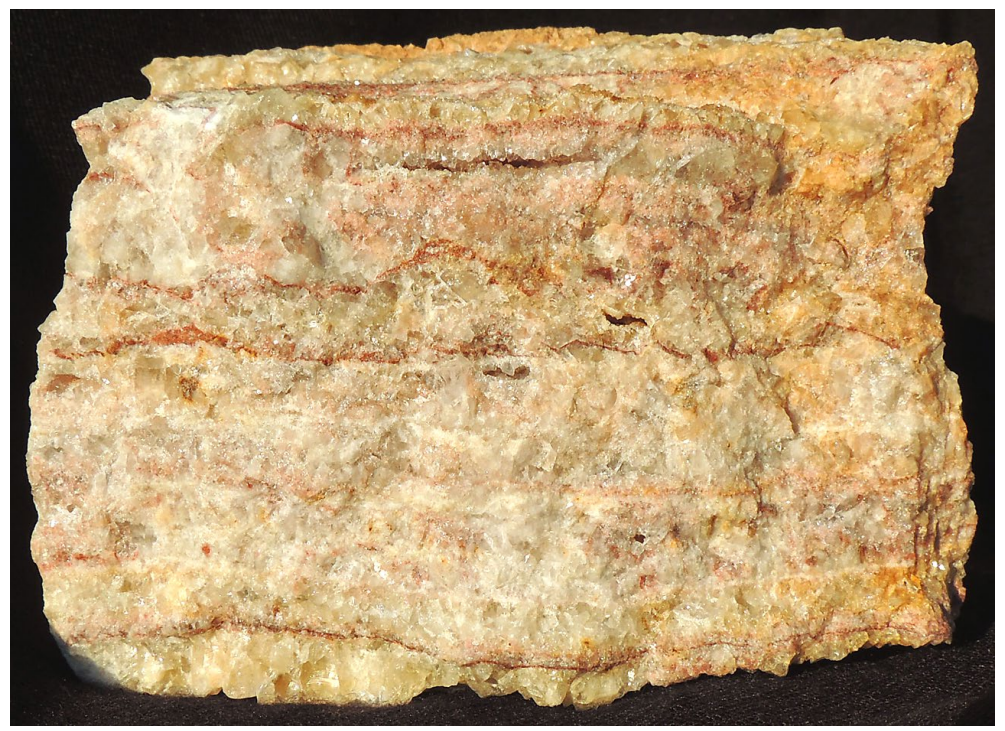

Obr. 5 Žilovina prvního typu; rozměry vzorku $10 \times 7 \mathrm{~cm}$; foto R. Gramblička. vých difrakčních maxim byly popsány profilovou funkcí Pseudo-Voigt a upřesněny profilovým fitováním v programu HighScore Plus. Mřížkové parametry byly vypřesněny metodou nejmenších čtverců pomocí programu Celref (Laugier, Bochu 2011).

Chemické složení namibitu a bismutoferritu bylo kvantitativně studováno pomocí elektronového mikroanalyzátoru Cameca SX100 (Národní muzeum, Praha) za podmínek: WD analýza, $15 \mathrm{kV}, 10 \mathrm{nA}$, průměr svazku elektronů $10 \mu \mathrm{m}$, použité standardy: albit (NaKa), sanidin (AlKa, SiKa, KKa), diopsid (MgKa), apatit (PKa, CaKa), vanadinit (PbMa, VKa), klinoklas (AsLa), $\mathrm{YVO}_{4}(\mathrm{YL \alpha})$, rodonit $(\mathrm{MnK} \alpha), \mathrm{Sn}(\mathrm{SnL} \alpha)$, halit $(\mathrm{ClK \alpha}), \mathrm{Bi}(\mathrm{BiM} \alpha)$, celestin $(\mathrm{SrL} \beta, \mathrm{SK} \alpha)$, hematit (FeKa), chalkopyrit (CuKa), ZnO $(\mathrm{ZnK} \alpha)$, Co $(\mathrm{CoK} \alpha)$, baryt $(\mathrm{BaL} \beta)$, LiF (FKa), $\mathrm{Cr}_{2} \mathrm{O}_{3}(\mathrm{CrK \alpha})$. Obsahy výše uvedených prvkủ, které nejsou zahrnuty $v$ tabulkách, byly kvantitativně analyzovány, ale zjištěné obsahy byly pod detekčním limitem (cca 0.01 - 0.05 hm. \% pro jednotlivé prvky). Získaná data byla korigována za použití software PAP (Pouchou, Pichoir 1985). Kvalitativní chemické analýzy bismutitu byly provedeny pomocí energiově disperzního spektrometru Oxford Instruments X-Max 20 na elektronovém mikroskopu Tescan Mira3 GMU (Česká geologická služba, Praha) při urychlovacím napětí $15 \mathrm{kV}$.

Ramanova spektra bismutitu, namibitu a bismutoferritu byla pořízena za pomoci Ramanova disperzního spektrometru DXR (Thermo Scientific) s konfokálním mikroskopem Olympus (Národní muzeum, Praha). Spektra byla získána za použití červeného laseru (633 nm) o výkonu $6 \mathrm{~mW}$ v měřícím rozsahu $38-2000 \mathrm{~cm}^{-1}$, za použití objektivu $10 \times$ a spot apertury $25 \mu \mathrm{m}$. Načítací čas na sken $1 \mathrm{~s}$; celkem 1800 skenů pro bismutit, 120 skenů pro namibit a 800 skenů pro bismutoferrit. U získaných spekter byly aplikovány korekce na fluorescenci. Interpretace Ramanových spekter byla provedena s prìhlédnutím k publikacím Chukanov, Vigasina (2020); Grice (2002); Selvamani et al. (2016); Frost et al. (2006, 2010, 2011); Kolitsch, Giester (2000); Plášil et al. (2018); Hardcastle, Wachs (1992); Taylor et al. (1984); Jones, Jackson (1993) a k pracím dalších autorů v nich citovaných.

\section{Výsledky mineralogického výzkumu}

Mineralizace s namibitem byla nalezena $\checkmark$ materiálu jedné ze starých pinek (obr. 2) $\checkmark$ hrubě krystalické fluoritové žilovině. $V$ prostoru této pinky byla druhým z autorů (RG) vyhloubena $4 \mathrm{~m}$ hluboká sonda, která měla prozkoumat charakter fluoritové žíly (obr. 3). Výplň hlavní žily však nebyla zachycena, patrně byla na většině své mocnosti již dříve vytěžena. $Z$ profilu vykopané sondy (obr. 4) vyplývá, že tato žíla do hloubky postupně vykliňuje. Na základě studia haldového materiálu Ize usuzovat na približnou stavbu hlavní žíly, která je tvořena třemi odlišnými typy žiloviny. Jde především o středně zrnitou křemen-fluoritovou žilovinu s pásko- 
vanou texturou (obr. 5). Páskované polohy bělavého a bledožlutého, zčásti i železitými oxidy zbarveného hnědočerveného fluoritu se střídají s tenkými vrstvami křemene a chalcedonu. $V$ plochých dutinách bývají vyvinuty až $1 \mathrm{~cm}$ velké čiré až nazelenalé kubické krystaly fluoritu, obvykle porostlé mladším drúzovitým křemenem, na který místy narůstají čiré, oboustranně omezené krystaly křištálu. Výjimečný byl nález dutiny s korodovanými krychlemi fluoritu o hraně do $4 \mathrm{~cm}$ a krystaly křištálu do $1 \mathrm{~cm}$. V menším množství je prítomna hrubě zrnitá fluoritová žilovina $\mathrm{s}$ všesměrnou, místy brekciovitou texturou, obsahující zrna a úlomky krystalů až $5 \mathrm{~cm}$ velkých. Větší drúzové dutiny se zonálními krychlovými krystaly fluoritu do $3 \mathrm{~cm}$ velikosti bývají vyplněny mladší jemnozrnnou brekcií. Posledním morfologickým typem je brekcie tvořená jemnozrnnou křemen-fluoritovou základní hmotou, která tmelí ostrohranné fragmenty fluoritových krystalů předchozího typu žiloviny. Tato jemnozrnná brekcie vyplňuje centrální část žíly. Hlavní žílu o předpokládané mocnosti 1 - $1.5 \mathrm{~m}$ (při povrchu) doprovázejí 2 až 4 drobnější odžilky o mocnostech 5 - $15 \mathrm{~cm}$, tvořené hrubozrnným, bledě žlutým, šedozeleným až fialovým fluoritem s páskovanou texturou. Centrální partie odžilků tvoří bílý nebo hematitem zbarvený křemen, často s palisádovou texturou a četnými drúzovými dutinami. Krystaly křemene, které dosahují velikosti $2 \mathrm{~cm}$, mají často vyvinuté jen pyramidální zakončení. Místy, zejména $v$ připovrchových partiích, se dochovalo jen křemenné jádro, z obou stran s hojnými negativy po krystalech fluoritu (obr. 6). Na těchto bočních žilách tvoří starší generace fluoritu zelené až fialové oktaedrické či rombododekaedrické krystaly, nezřídka s hypoparalelními nárůsty drobných zonálních žluto-fialových krystalů fluoritu. $V$ silně zvětralé hornině mezi hlavní žilou a vedlejšími žilami jsou vyvinuté tenké prožilky světle až tmavě žlutého rozpadavého fluoritu, který v podélných dutinách tvoří drúzy kubických krystalů o velikosti do $1 \mathrm{~cm}$ (obr. 7).

$\mathrm{SiO}_{2}$ hmoty jsou na lokalitě zastoupené především křemenem, který tvoří tenké žilky $v$ žilovině či centrální výplně žil, často $v$ polyfázovém drúzovitém vývoji. $V$ některých dutinách jsou prítomny i náteky chalcedonu. $\checkmark$ haldovém materiálu se vyskytují i velké úlomky masivního křemene rohovcovitého vzhledu s četnými otisky po krystalech fluoritu. Barva křemene je obvykle bílá, světle šedá či hnědočervená až tmavohnědá, vzácně se v dutinách vyskytl světle fialový ametyst.

Supergenní Bi zrudnění s namibitem, bismutoferritem a bismutitem bylo nalezeno pouze $v$ asi dvaceti úlomcích fluoritové žiloviny druhého a třetího typu. Místy se $v$ těchto typech žiloviny vyskytují zrna a krystalové pseudomorfózy limonitu po pyritu a chalkopyritu. $V$ nezvětralé formě však tyto sulfidy nebyly na lokalitě zjištěny.

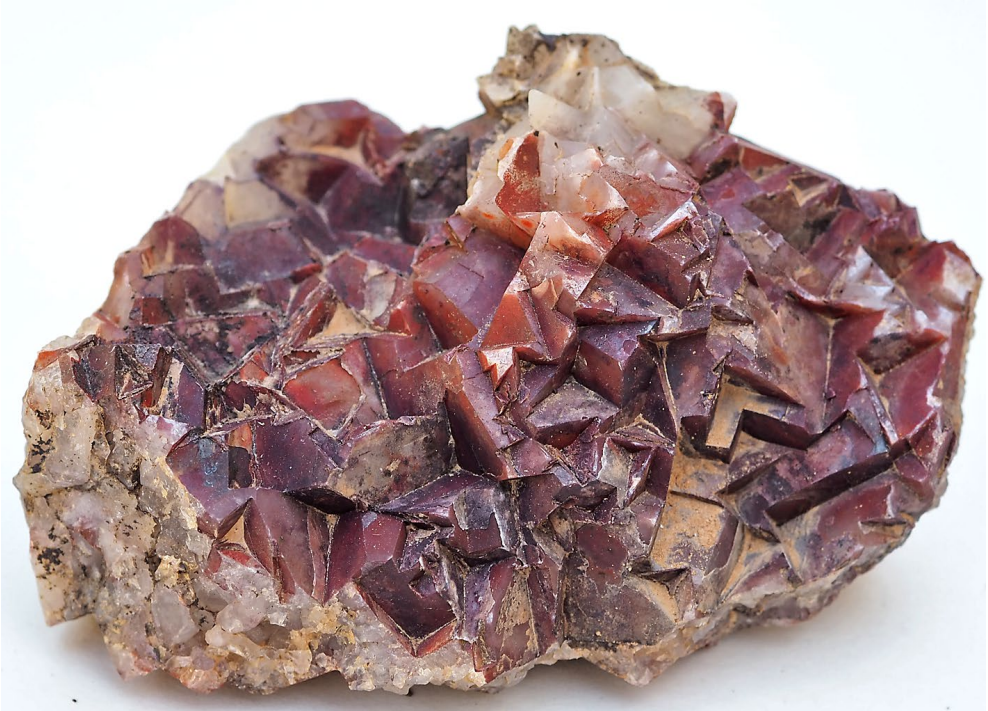

Obr. 6 Křemenná žilovina $s$ negativními otisky po krystalech fluoritu; velikost vzorku $8 \times 4 \mathrm{~cm}$; foto $P$. Pauliš.

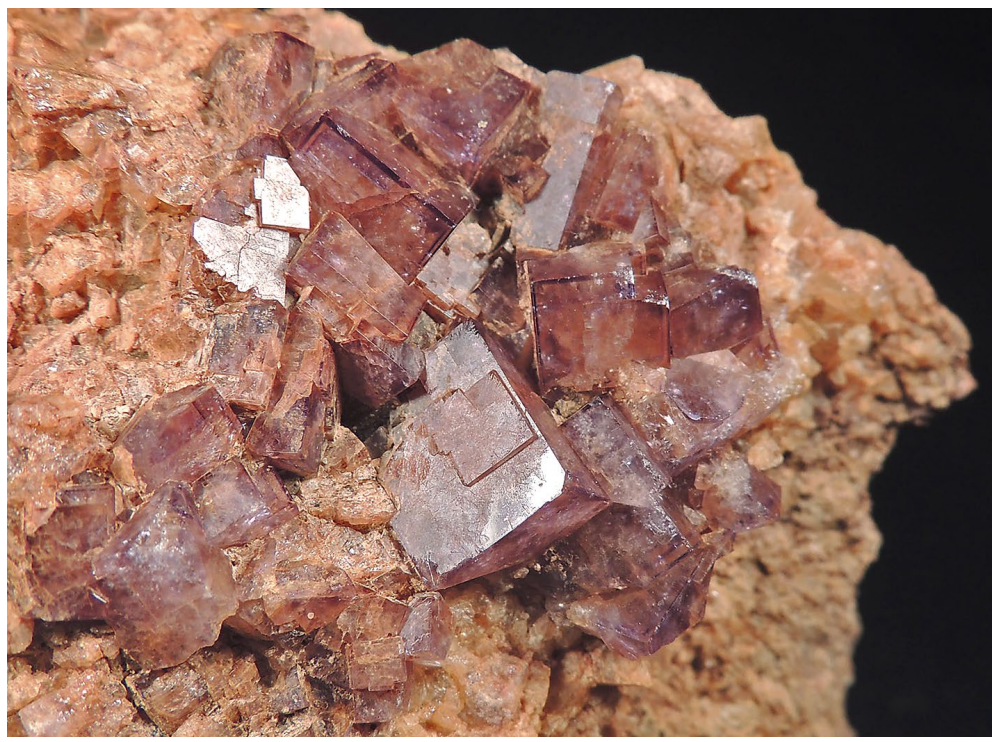

Obr. 7 Drúza fluoritu ze žíly Nadějná; šiřrka záběru 4.5 cm; foto R. Gramblička

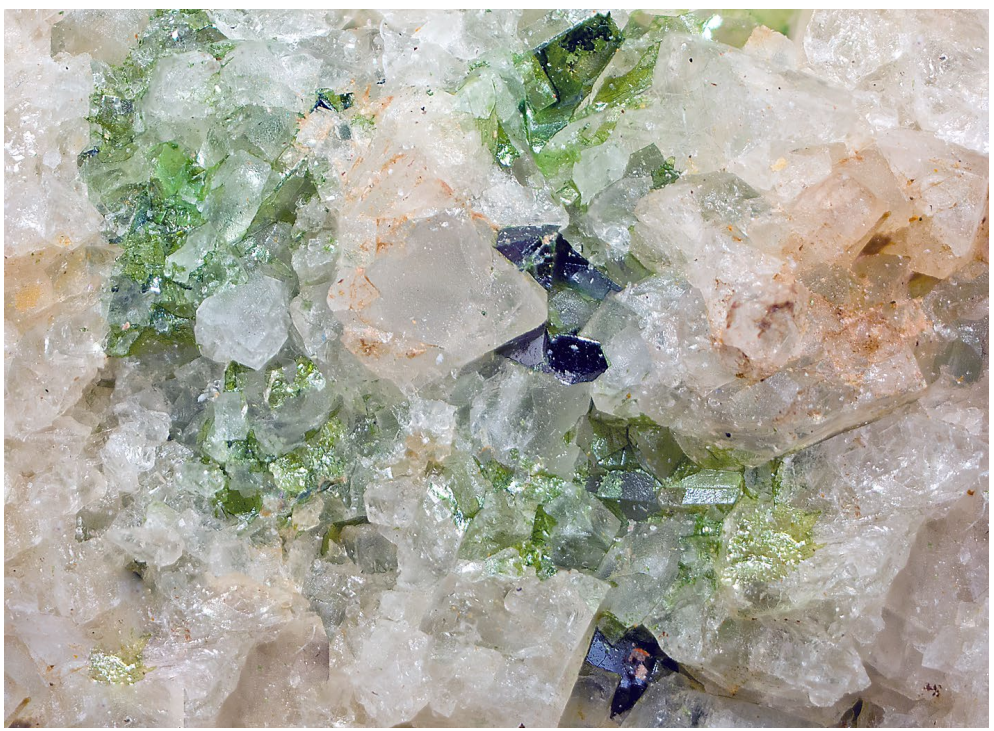

Obr. 8 Povlaky namibitu na štěpných plochách fluoritu; šiřka záběru 4 $\mathrm{mm}$; foto P. Fuchs. 


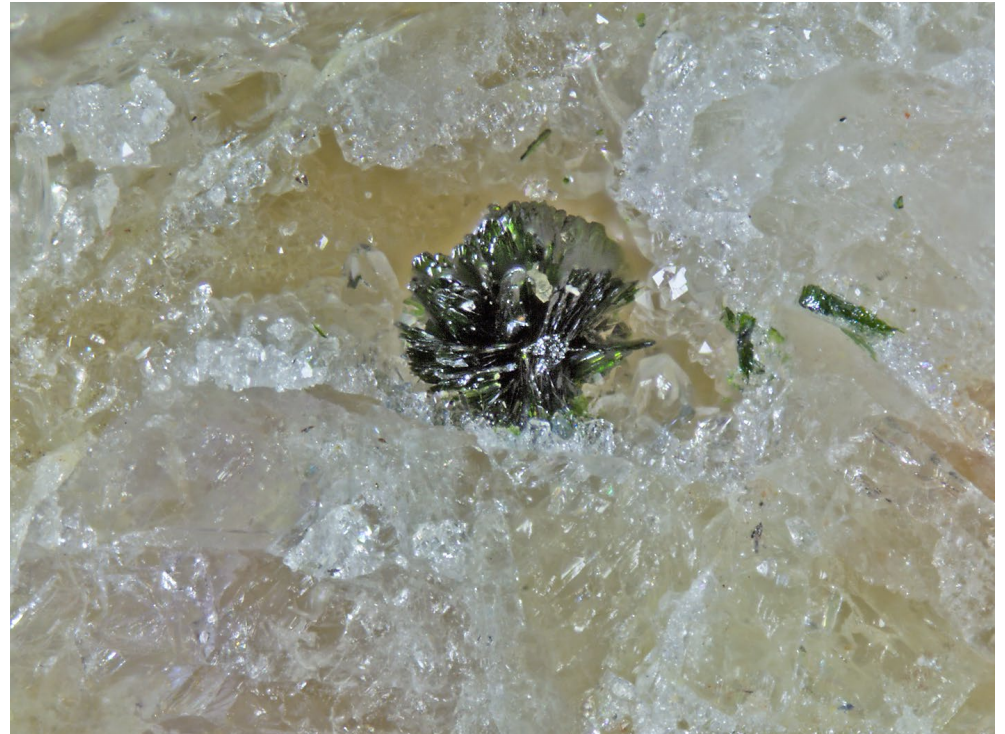

Obr. 9 Agregát krystalů namibitu v dutině křemene; šírka záběru 3 mm; foto $B$. Bureš.

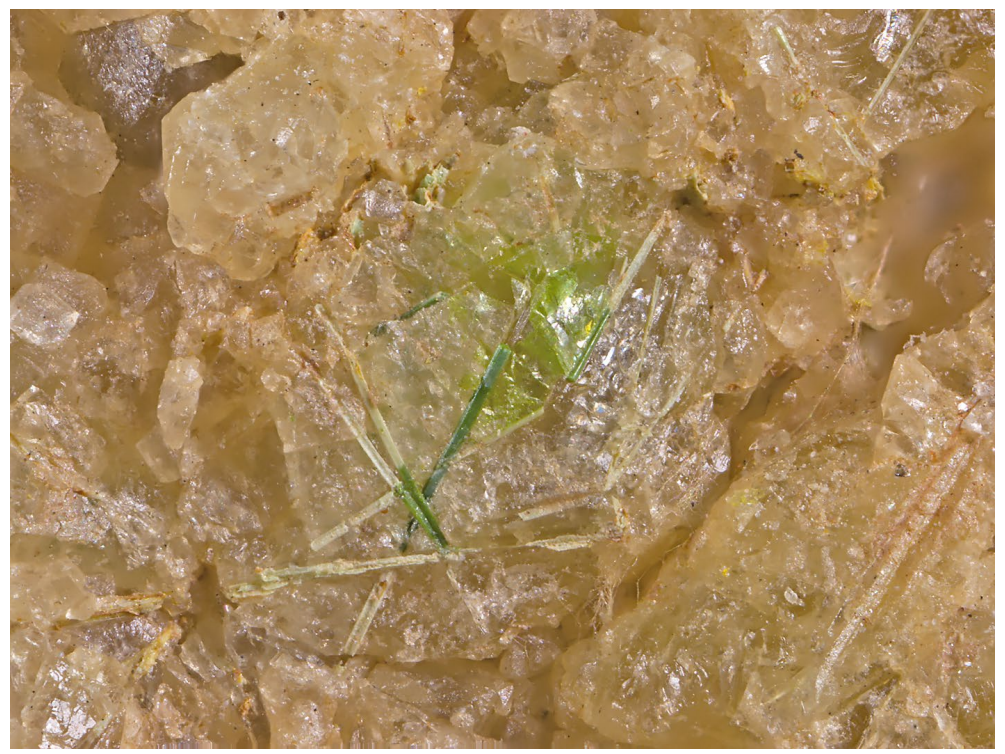

Obr. 10 Jehlicovitý bismutit, zčásti zelený namibit ve fluoritu; šířka záběru $4 \mathrm{~mm}$; foto $B$. Bureš.

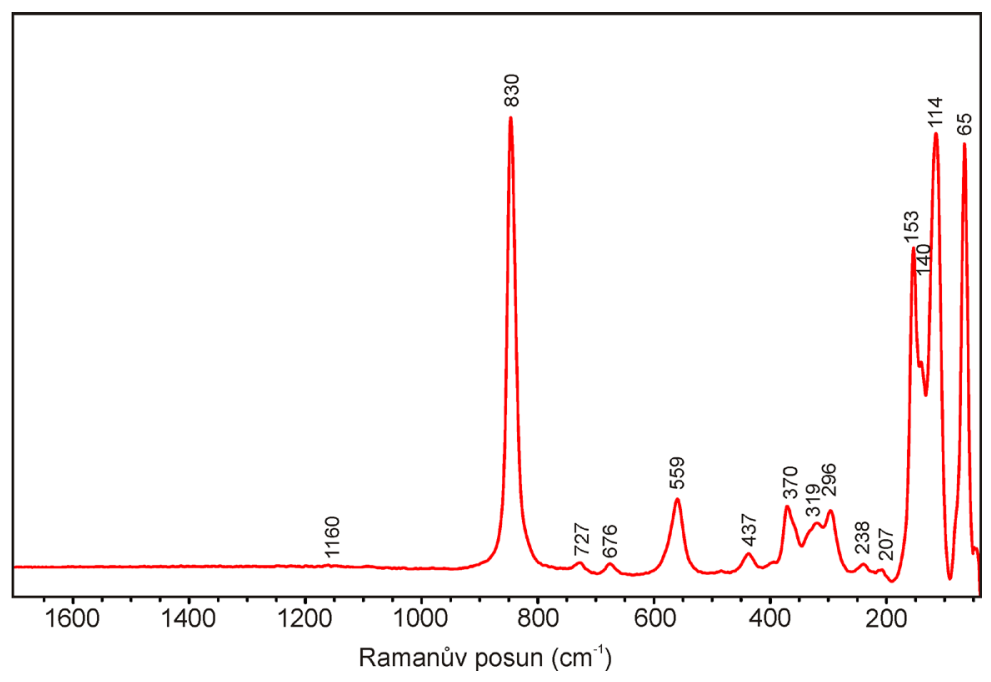

Obr. 11 Ramanovo spektrum namibitu ze žíly Nadějná.

\section{Charakteristika supergenních Bi mi-} nerálů

Namibit, triklinický vanadát mědi a bismutu - $\mathrm{Cu}(\mathrm{BiO})_{2}\left(\mathrm{VO}_{4}\right)(\mathrm{OH})$ je poměrně vzácný minerál, který byl dosud celosvětově zjištěn zhruba na 25 lokalitách. Popsán byl von Knorringem a Sahamou (1981) z Namibie. $\checkmark$ ČR byl zatím zjištěn pouze $v$ Jáchymově $\checkmark$ haldovém materiálu dolu Zimní Eliáš v křemenných žilkách vyvinutých podél kontaktu ruly s křemenným porfyrem (Mrázek et al. 1994; Ondruš et al. 1997), kde tvoří světle až tmavě zelené povlaky a kulovité agregáty jehličkovitých krystalů o délce do $0.3 \mathrm{~mm}$ $v$ asociaci $s$ beyeritem, eulytinem, bismutitem a vzácným pucheritem. Ojedinělý nález byl též učiněn $v$ materiálu ze žíly $\mathrm{R} z$ patra 90 m šachty Jiřina (Škácha et al. 2019).

$\mathrm{Na}$ žíle Nadějná u Kotliny tvoří namibit tenké, trávově zelené povlaky na puklinách mezi fluoritovými zrny a na štěpných plochách fluoritu (obr. 8). V drobných drúzových dutinách křemene jsou vzácnější, tmavě zelené, skelně lesklé, ježkovité, maximálně 0.2 $\mathrm{mm}$ velké agregáty tvořené plochými jehličkovitými krystaly (obr. 9). Pouze na několika málo vzorcích tvoři namibit pseudomorfózy po jehlicích bismutitu (obr. 10), které vznikly kompletní přeměnou primárního minerálu $\mathrm{Bi}$, patrně bismutinu či emplektitu.

Rentgenová prášková data namibitu z Nadějné žily (tab. 1) odpovídají publikovaným údajům (von Knorring, Sahama 1981) i teoretickému záznamu vypočtenému z krystalových strukturních dat (Kolitsch, Giester 2000). Původně byl namibit považován za monoklický minerál s $C$-centrovanou základní celou a parametry $a \sim 11.87, b \sim 3.70, c \sim$ $7.49 \AA, \beta \sim 109.7^{\circ}, V \sim 310 \AA^{3}$ (von Knorring, Sahama 1981; Mrázek et al. 1994); novější studium krystalové struktury prokázalo jeho triklinickou symetrii (Kolitsch, Giester 2000). Zpřesněné parametry základní cely studovaného namibitu velmi dobře odpovídají publikovaným datům pro namibit z ložiska Iron Monarch v jižní Austrálii, dolu Nagatara v Japonsku a pegmatitu Alakurtti (poloostrov Kola) v Rusku (tab. 2).

V BSE obraze je studovaný minerál chemicky homogenní. Při studiu jeho chemického složení (tab. 3) bylo vedle obsahů hlavních složek ( $\mathrm{Cu}, \mathrm{Bi}$ a $\mathrm{V}$ ) zjištěno minoritní zastoupení Fe (0.02 - 0.05 apfu), P (0.01 - 0.03 apfu), Cr (do 0.02 apfu) a Pb (do 0.01 apfu ). Empirický vzorec namibitu (průměr 10 bodových analýz) je na bázi $\mathrm{V}+\mathrm{P}+\mathrm{Cr}=1 \mathrm{apfu}$ možno vyjádřit jako $\left(\mathrm{Cu}_{0.93} \mathrm{Fe}_{0.03} \mathrm{Ca}_{0.01}\right)_{\Sigma 0.97}$ $(\mathrm{BiO})_{1.79}\left(\mathrm{~V}_{0.97} \mathrm{P}_{0.02} \mathrm{Cr}_{0.01}\right)_{\Sigma 1.00} \mathrm{O}_{4}(\mathrm{OH})_{0.75}$.

Ramanovo spektrum namibitu (obr. 11) vykazuje velmi slabý pás při $1160 \mathrm{~cm}^{-1}$, který Ize priiradit deformačním vibracím $\delta \mathrm{Cu}-\mathrm{OH}$ a deformačním vibracím $\delta \mathrm{BiOH}$. Velmi intenzivní pás při $830 \mathrm{~cm}^{-1}$ pak souvisí se symetrickými valenčními vibracemi $v_{1} V_{O_{4}}{ }^{3-}$, velmi slabé pásy při 727 a $676 \mathrm{~cm}^{-1} \mathrm{~s}$ trojnásobně 
Tabulka 1 Rentgenová prášková data namibitu ze žily Nadějná u Kotliny

\begin{tabular}{|c|c|c|c|c|c|c|c|c|c|c|c|c|c|c|c|c|c|}
\hline$h$ & $k$ & 1 & $d_{o b s}$ & $I_{o b s}$ & $d_{\text {calc }}$ & $h$ & $k$ & I & $d_{o b s}$ & $I_{o b s}$ & $d_{\text {calc }}$ & $h$ & $k$ & 1 & $d_{o b s}$ & $I_{o b s}$ & $d_{\text {calc }}$ \\
\hline 0 & 0 & 1 & 7.023 & 62 & 7.033 & 1 & 2 & 1 & 2.2843 & 13 & 2.2813 & -1 & 2 & 4 & 1.6418 & 31 & 1.6419 \\
\hline-1 & 0 & 0 & 5.565 & 98 & 5.577 & -2 & 0 & 3 & 2.1961 & 4 & 2.1959 & 0 & 3 & 3 & 1.5731 & 8 & 1.5721 \\
\hline-1 & 0 & 1 & 5.323 & 13 & 5.332 & 0 & -2 & 3 & 2.0540 & 14 & 2.0548 & 1 & 4 & 0 & 1.5384 & 7 & 1.5386 \\
\hline 1 & 0 & 1 & 3.791 & 2 & 3.792 & -1 & 2 & 3 & 2.0501 & 14 & 2.0505 & -2 & -2 & 4 & 1.5331 & 9 & 1.5330 \\
\hline-1 & 0 & 2 & 3.567 & 63 & 3.566 & 2 & 1 & 1 & 2.0401 & 1 & 2.0396 & -3 & -2 & 1 & 1.5292 & 9 & 1.5288 \\
\hline 0 & 0 & 2 & 3.517 & 39 & 3.517 & -2 & 2 & 3 & 1.9984 & 11 & 1.9989 & -1 & -4 & 2 & 1.5 & 2 & 1.5186 \\
\hline-1 & 2 & 1 & 3.277 & 73 & 3.281 & -2 & -2 & 1 & 1.9922 & 10 & 1.9926 & 3 & -2 & 2 & 1.5081 & 5 & 1.5080 \\
\hline-2 & 1 & 1 & 3.060 & 3 & 3.061 & -3 & 0 & 2 & 1.9343 & 7 & 1.9350 & -2 & 4 & 3 & 1.4813 & 4 & 1.4812 \\
\hline 0 & 1 & 2 & 3.012 & 100 & 3.015 & 2 & -2 & 2 & 1.8995 & 2 & 1.8998 & -3 & -1 & 4 & 1.4775 & 3 & 1.4778 \\
\hline-2 & 0 & 1 & 2.953 & 18 & 2.956 & -3 & 0 & 0 & 1.8584 & 11 & 1.8590 & 1 & -4 & 3 & 1.4543 & 4 & 1.4536 \\
\hline-2 & 0 & 0 & 2.786 & 36 & 2.789 & -3 & 1 & 3 & 1.8223 & $<1$ & 1.8214 & 1 & 1 & 4 & 1.4454 & $<1$ & 1.4456 \\
\hline-1 & -2 & 1 & 2.670 & 58 & 2.671 & -3 & 0 & 3 & 1.7781 & 6 & 1.7773 & -4 & 0 & 3 & 1.4285 & 1 & 1.4285 \\
\hline-2 & 0 & 2 & 2.668 & 56 & 2.666 & -2 & -2 & 3 & 1.7485 & 12 & 1.7482 & -3 & 4 & 3 & 1.4143 & 2 & 1.4141 \\
\hline-1 & 2 & 2 & 2.626 & 9 & 2.625 & -1 & 3 & 3 & 1.7234 & 7 & 1.7239 & -4 & 3 & 0 & 1.4101 & 3 & 1.4103 \\
\hline 1 & 0 & 2 & 2.604 & 17 & 2.605 & 2 & 2 & 1 & 1.7191 & 10 & 1.7194 & -4 & 0 & 0 & 1.3944 & 2 & 1.3943 \\
\hline-1 & 0 & 3 & 2.4814 & 9 & 2.4806 & -2 & 2 & 4 & 1.6517 & 3 & 1.6525 & -4 & 1 & 4 & 1.3663 & 1 & 1.3661 \\
\hline-1 & -2 & 2 & 2.3902 & 7 & 2.3918 & 0 & -2 & 4 & 1.6453 & 11 & 1.6450 & 3 & 2 & 1 & 1.3502 & 2 & 1.3501 \\
\hline-1 & 1 & 3 & 2.3570 & 8 & 2.3581 & & & & & & & & & & & & \\
\hline
\end{tabular}

Tabulka 2 Parametry základní cely namibitu (pro triklinickou prostorovou grupu P-1)

\begin{tabular}{ccccc}
\hline & tato práce & Kolitsch, Giester (2000) & Uehara, Shirose (2013) & Borisova et al. (2012) \\
\hline$a[\AA]$ & $6.2096(18)$ & $6.210(1)$ & $6.216(4)$ & $6.220(8)$ \\
$b[\AA]$ & $7.395(2)$ & $7.398(1)$ & $7.384(6)$ & $7.406(8)$ \\
$c[\AA]$ & $7.4708(18)$ & $7.471(1)$ & $7.467(6)$ & $7.500(2)$ \\
$\alpha\left[^{\circ}\right]$ & $90.1(2)$ & $90.10(1)$ & $90.19(8)$ & $90.20(11)$ \\
$\beta\left[^{\circ}\right]$ & $108.73(15)$ & $108.73(1)$ & $108.65(7)$ & $108.80(10)$ \\
$Y\left[^{\circ}\right]$ & $107.45(19)$ & $107.47(1)$ & $107.36(8)$ & $107.36(15)$ \\
$V\left[\AA^{3}\right]$ & $308.09(15)$ & $308.22(1)$ & $308.1(3)$ & $310.25(9)$ \\
\hline
\end{tabular}

Tabulka 3 Chemické složení namibitu ze žily Nadějná u Kotliny

\begin{tabular}{lrrrrrrrrrrr}
\hline & mean & 1 & 2 & 3 & 4 & 5 & 6 & 7 & 8 & 9 & 10 \\
\hline $\mathrm{CaO}$ & 0.06 & 0.12 & 0.12 & 0.10 & 0.10 & 0.11 & 0.09 & 0.00 & 0.00 & 0.00 & 0.00 \\
$\mathrm{PbO}$ & 0.14 & 0.47 & 0.00 & 0.36 & 0.30 & 0.23 & 0.00 & 0.00 & 0.00 & 0.00 & 0.00 \\
$\mathrm{CuO}$ & 12.61 & 12.54 & 12.58 & 12.77 & 12.70 & 12.54 & 12.57 & 12.59 & 12.56 & 12.71 & 12.50 \\
$\mathrm{Cr}_{2} \mathrm{O}_{3}$ & 0.11 & 0.19 & 0.20 & 0.08 & 0.11 & 0.10 & 0.15 & 0.08 & 0.08 & 0.05 & 0.09 \\
$\mathrm{Fe}_{2} \mathrm{O}_{3}$ & 0.39 & 0.25 & 0.40 & 0.35 & 0.36 & 0.30 & 0.27 & 0.43 & 0.40 & 0.46 & 0.66 \\
$\mathrm{Bi}_{2} \mathrm{O}_{3}$ & 71.21 & 71.41 & 70.89 & 71.26 & 71.88 & 71.05 & 71.75 & 71.26 & 71.00 & 71.09 & 70.54 \\
$\mathrm{P}_{2} \mathrm{O}_{5}$ & 0.24 & 0.13 & 0.21 & 0.23 & 0.25 & 0.29 & 0.22 & 0.25 & 0.25 & 0.33 & 0.26 \\
$\mathrm{~V}_{2} \mathrm{O}_{5}$ & 15.11 & 15.50 & 15.13 & 15.42 & 15.00 & 15.16 & 14.90 & 14.86 & 15.19 & 14.86 & 15.04 \\
$\mathrm{H}_{2} \mathrm{O}^{*}$ & 1.15 & 1.04 & 1.12 & 1.13 & 1.24 & 1.09 & 1.18 & 1.21 & 1.09 & 1.22 & 1.18 \\
\hline total & 101.02 & 101.65 & 100.65 & 101.70 & 101.94 & 100.87 & 101.13 & 100.68 & 100.57 & 100.72 & 100.27 \\
\hline $\mathrm{Ca}$ & 0.007 & 0.012 & 0.012 & 0.010 & 0.010 & 0.011 & 0.010 & 0.000 & 0.000 & 0.000 & 0.000 \\
$\mathrm{~Pb}$ & 0.004 & 0.012 & 0.000 & 0.009 & 0.008 & 0.006 & 0.000 & 0.000 & 0.000 & 0.000 & 0.000 \\
$\mathrm{Cu}$ & 0.927 & 0.902 & 0.920 & 0.923 & 0.940 & 0.916 & 0.936 & 0.942 & 0.920 & 0.947 & 0.923 \\
$\mathrm{Fe}$ & 0.028 & 0.018 & 0.029 & 0.025 & 0.027 & 0.022 & 0.020 & 0.032 & 0.029 & 0.034 & 0.049 \\
$\mathrm{Bi}$ & 1.787 & 1.754 & 1.769 & 1.759 & 1.816 & 1.772 & 1.823 & 1.821 & 1.776 & 1.809 & 1.779 \\
$\mathrm{Cr}$ & 0.009 & 0.014 & 0.015 & 0.006 & 0.009 & 0.008 & 0.012 & 0.006 & 0.006 & 0.004 & 0.007 \\
$\mathrm{P}$ & 0.020 & 0.010 & 0.017 & 0.019 & 0.021 & 0.024 & 0.018 & 0.021 & 0.021 & 0.028 & 0.022 \\
$\mathrm{~V}$ & 0.971 & 0.975 & 0.967 & 0.975 & 0.971 & 0.969 & 0.970 & 0.973 & 0.973 & 0.969 & 0.972 \\
$\mathrm{OH}$ & 0.747 & 0.661 & 0.723 & 0.722 & 0.810 & 0.703 & 0.776 & 0.800 & 0.705 & 0.803 & 0.770 \\
\hline $\mathrm{mean}$ & & & & & & & & & & &
\end{tabular}


Tabulka 4 Chemické složení bismutoferritu ze žily Nadějná u Kotliny

\begin{tabular}{lrrrrrr}
\hline & mean & 1 & 2 & 3 & 4 & 5 \\
\hline $\mathrm{CaO}$ & 0.10 & 0.11 & 0.10 & 0.11 & 0.09 & 0.11 \\
$\mathrm{MgO}$ & 0.12 & 0.08 & 0.16 & 0.12 & 0.09 & 0.13 \\
$\mathrm{CuO}$ & 0.53 & 0.51 & 0.64 & 0.51 & 0.44 & 0.55 \\
$\mathrm{Al}_{2} \mathrm{O}_{3}$ & 0.19 & 0.20 & 0.16 & 0.18 & 0.21 & 0.22 \\
$\mathrm{Fe}_{2} \mathrm{O}_{3}$ & 29.72 & 29.77 & 29.99 & 29.70 & 29.41 & 29.75 \\
$\mathrm{Bi}_{2} \mathrm{O}_{3}$ & 41.67 & 42.66 & 41.27 & 41.59 & 42.00 & 40.85 \\
$\mathrm{SiO}_{2}$ & 23.37 & 23.43 & 23.88 & 23.12 & 23.45 & 22.97 \\
$\mathrm{H}_{2} \mathrm{O}^{*}$ & 1.19 & 1.27 & 0.95 & 1.31 & 1.05 & 1.36 \\
\hline total & 96.90 & 98.03 & 97.15 & 96.64 & 96.74 & 95.94 \\
\hline $\mathrm{Ca}$ & 0.010 & 0.010 & 0.009 & 0.010 & 0.008 & 0.010 \\
$\mathrm{Mg}$ & 0.015 & 0.010 & 0.020 & 0.015 & 0.011 & 0.017 \\
$\mathrm{Cu}$ & 0.034 & 0.033 & 0.040 & 0.033 & 0.028 & 0.036 \\
$\mathrm{Al}$ & 0.020 & 0.020 & 0.016 & 0.018 & 0.021 & 0.023 \\
$\mathrm{Fe}$ & 1.914 & 1.912 & 1.890 & 1.933 & 1.888 & 1.949 \\
$\mathrm{Bi}$ & 0.920 & 0.939 & 0.891 & 0.928 & 0.924 & 0.917 \\
$\mathrm{Si}$ & 2.000 & 2.000 & 2.000 & 2.000 & 2.000 & 2.000 \\
$\mathrm{OH}$ & 0.679 & 0.723 & 0.531 & 0.756 & 0.597 & 0.790 \\
\hline
\end{tabular}

mean - průměr z pěti bodových analýz; koeficienty empirického vzorce dopočítány na bázi $\mathrm{Si}=2$ apfu; obsah $\mathrm{H}_{2} \mathrm{O}^{*}$ dopočítaný na základě vyrovnání nábojů.
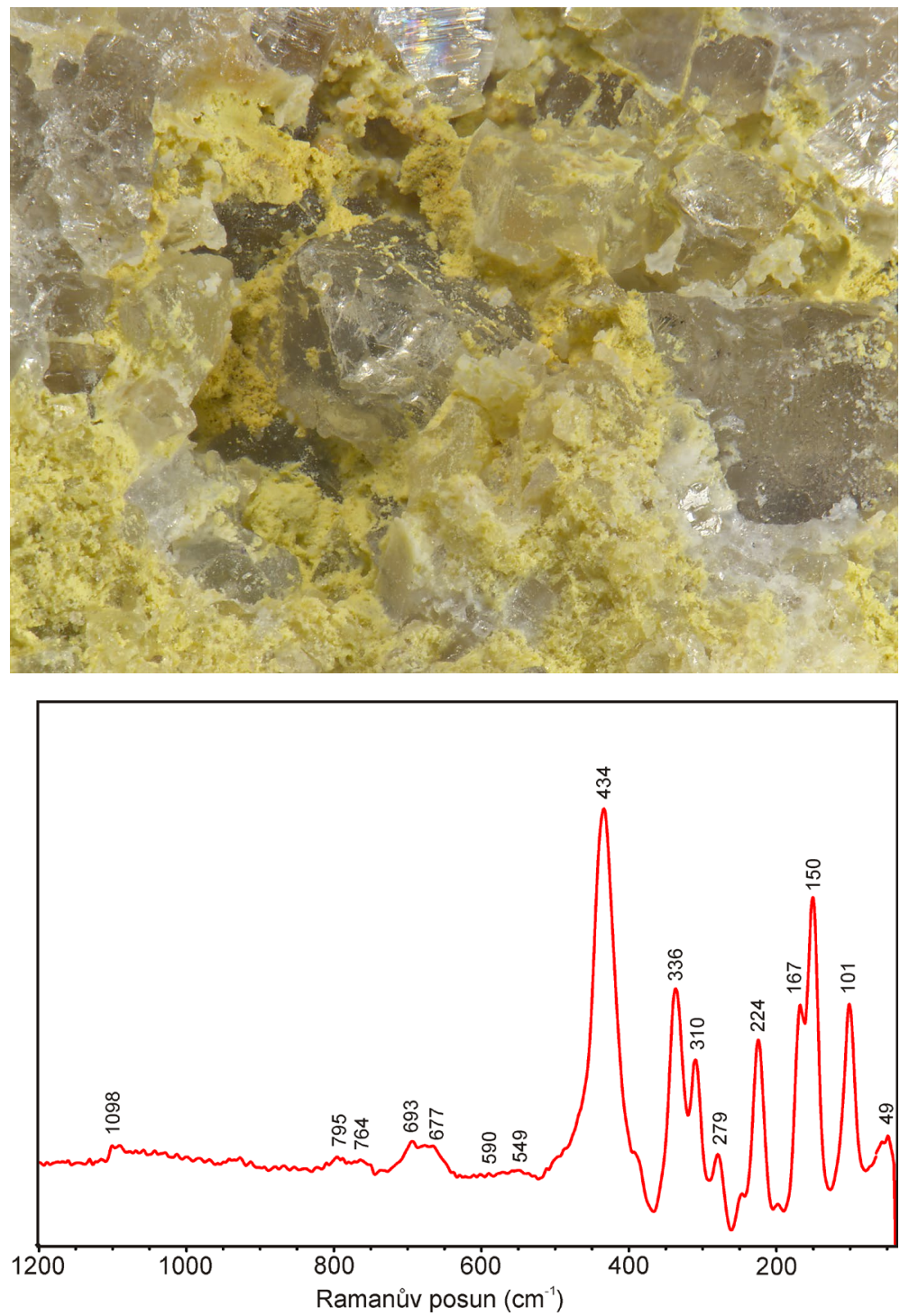

degenerovanými antisymetrickými vibracemi $v_{3} V_{O_{4}}{ }^{3-}$, pásy střední intenzity při 437 a $370 \mathrm{~cm}^{-1} \mathrm{~s}$ trojnásobně degenerovanými deformačními vibracemi $v_{4}(\delta) \mathrm{VO}_{4}^{3-}$ a při 319 a $296 \mathrm{~cm}^{-1} \mathrm{~s}$ dvojnásobně degenerovanými deformačními vibracemi $v_{2}(\delta) \mathrm{VO}_{4}{ }^{3-} . \mathrm{V}$ oblasti $559-296 \mathrm{~cm}^{-1}$ se mohou vyskytovat valenční a deformační vibrace $\mathrm{Bi}-\mathrm{O}$ a $\mathrm{Cu}-\mathrm{O}$ a deformační vibrace $\mathrm{Bi}-\mathrm{O}-\mathrm{Bi}$. Uvedené vibrace se mohou překrývat $s$ deformačními vibracemi $\mathrm{VO}_{4}{ }^{3-}$. Slabé pásy při 238 a 207 $\mathrm{cm}^{-1}$ a velmi intenzivní pásy při 153, 140, 114 a $65 \mathrm{~cm}^{-1}$ byly přiřazeny mřížkovým modům.

Spolu s namibitem se ve světlé fluoritové žilovině vyskytlo několik vzorků bismutoferritu, který tvoří na puklinách a v drobných dutinách fluoritu žluté práškovité agregáty (obr. 12). V BSE obraze je studovaný minerál chemicky homogenní. Při studiu jeho chemického složení (tab. 4) byly vedle hlavních komponent $(\mathrm{Fe}, \mathrm{Bi}$ a Si) zjištěny minoritní obsahy Cu (0.03 - 0.04 apfu), Al (0.02 apfu), Ca (0.01 apfu) a Mg (0.01 - 0.02 apfu). Empirický vzorec bismutoferritu (průměr pěti bodových analýz) je na bázi Si = 1 apfu možno vyjádřit jako $\left(\mathrm{Fe}_{1.91} \mathrm{Cu}_{0.03} \mathrm{Mg}_{0.02} \mathrm{Al}_{0.02} \mathrm{Ca}_{0.01}\right)_{\Sigma 1.99}$ $\mathrm{Bi}_{0.92}\left(\mathrm{SiO}_{4}\right)_{2.00}(\mathrm{OH})_{0.68}$.

Ramanovo spektrum bismutoferritu (obr. 13) vykazuje v oblasti $1900-1100 \mathrm{~cm}^{-1}$ pásy velmi slabé intenzity prakticky splývající s pozadím, což vyloučilo jejich intepretaci. Proto bylo Ramanovo spektrum bismutoferritu interpretováno pouze $v$ oblasti nižších vlnočtů od $1100 \mathrm{~cm}^{-1}$. Velmi slabý asymetrický široký pás s vrcholem při $1098 \mathrm{~cm}^{-1}$ Ize přiřadit antisymetrickým valenčním vibracím $v_{\text {as }}$ Si-O-Si, v Si-O $O_{\text {terminal }}$ a deformačním vibracím $\delta \mathrm{Bi}-\mathrm{OH}$ a $\delta \mathrm{Cu}-\mathrm{OH}$, velmi slabé pásy při 795 a $764 \mathrm{~cm}^{-1}$ a slabé pásy prì 693 a $677 \mathrm{~cm}^{-1}$ symetrickým valenčním vibracím $v_{\mathrm{s}} \mathrm{Si}-\mathrm{O}-\mathrm{Si}$, velmi slabé pásy při 590 a 549 $\mathrm{cm}^{-1}$ valenčním pásům $\mathrm{Bi}-\mathrm{O}$ a $\mathrm{Bi}-\mathrm{O}-\mathrm{Bi}$. Velmi intenzivní pás při $434 \mathrm{~cm}^{-1}$ byl přiřazen valenční vibraci $v$ Si-O-Si, pásy při 336 a $310 \mathrm{~cm}^{-1}$, deformační vibraci $\delta \mathrm{Si}-\mathrm{O}-\mathrm{Si}$, deformační vibraci $\delta$ O-Si-O a deformační vibraci Bi-O-Bi, a valenčnim vibracím $\mathrm{Bi}-\mathrm{O}$ a Fe-O. Pásy různé intenzity prí 279 a 224 $\mathrm{cm}^{-1}$ souvisí $\mathrm{s}$ valenčními vibracemi $\mathrm{Bi}-\mathrm{O}$ a Bi-O-Bi, zatímco pásy při 167, 150, 101 a 49 $\mathrm{cm}^{-1}$ přísluší mřížkovým modům. Interpretace Ramanova spektra bismutoferritu byla provedena především s priihlédnutím $\mathrm{k}$ práci Frosta et al. (2010).

Obr. 12 Žluté práškovité agregáty bismutoferritu na fluoritové žilovině; šiřka záběru $4.5 \mathrm{~mm}$; foto L. Vrtiška.

Obr. 13 Ramanovo spektrum bismutoferritu ze žily Nadějná. 
Nenápadným a ojedinělým minerálem této lokality je bismutit, který tvoří ve fluoritové žilovině až $2 \mathrm{~mm}$ dlouhé žlutobílé jehličkovité krystaly (obr. 10). Jde patrně o pseudomorfózy po primárním Bi sulfidu (emplektitu či bismutinu). Některé jehličky jsou zčásti tvořené žlutavým bismutitem a zčásti zeleným namibitem. Ověřen byl pomocí semikvantitativní chemické analýzy (EDS), zjištěn byl pouze podstatný obsah Bi a stopy (0.X \%) Cu, Fe, Ca, Si, P a Al.

Ramanovo spektrum bismutitu (obr. 14) vykazuje velmi slabý široký pás s vrcholem při $1863 \mathrm{~cm}^{-1}$, který přísluší pravděpodobně vyšším harmonickým a/nebo kombinačním pásům, zatímco velmi slabý široký pás s vrcholem prí $1350 \mathrm{~cm}^{-1}$ souvisí s dvojnásobně degenerovanými $v_{3} \mathrm{CO}_{3}{ }^{2-}$ antisymetrickými valenčními vibracemi. Pás střední intenzity při $1069 \mathrm{~cm}^{-1}$ spolu se slabým pásem při $997 \mathrm{~cm}^{-1}$ byl prířazen $v_{1} \mathrm{CO}_{3}{ }^{2-}$ symetrické valenční vibraci. Pás nízké intenzity při 846 $\mathrm{cm}^{-1}$ je spojen $\mathrm{s}$ mimorovinnou deformační vibrací $v_{2}(\delta) \mathrm{CO}_{3}{ }^{2-}$ a velmi slabý pás při 667 $\mathrm{cm}^{-1} \mathrm{~s}$ překrývajícími se pásy dvojnásobně degenerované rovinné deformační vibrace $v_{4}(\delta) \mathrm{CO}_{3}^{2-} \mathrm{a}$ $\mathrm{s}$ valenční vibrací $v \mathrm{Bi}-\mathrm{O}$. Široký pás slabé intenzity $\mathrm{s}$ vrcholem prì $373 \mathrm{~cm}^{-1}$ byl priiřazen koincidujícím pásưm valenčních vibrací $\mathrm{Bi}-\mathrm{O}$ a deformační vibrací Bi-O-Bi. Velmi intenzivní pás při $164 \mathrm{~cm}^{-1}$ a intenzivní pás při $56 \mathrm{~cm}^{-1}$ prísluší mřížkovým modům.

\section{Závěr}

Namibit patří k poměrně vzácným minerálům. Jeho výskyt na drobné žíle s jednoduchou křemen-fluoritovou výplní je jeho druhým ověřeným výskytem v ČR po oblasti jáchymovského rudního revíru. Zdrojem Bi pro vznik tohoto supergenního minerálu byly primární Bi sulfidy, patrně emplektit či bismutin, které byly na lokalitě zcela přeměněny. Ve fluoritové žilovině dokládají jejich existenci drobné jehlicovité pseudomorfózy tvořené bismutitem a z části i namibitem. Zdrojem mědi byl emplektit či chalkopyrit, jehož prítomnost dokládají limonitové pseudomorfózy pseudotetraedrického habitu. Nejasný je zdroj vanadu, který byl patrně odvozen z okoložilných metamorfovaných hornin krušnohorského krystalinika. Nešlo by o výjimku, primární i supergenní vanadová mineralizace je uváděna z jáchymovského rudního revíru (Škácha et al. 2019) a nověji byla lokálně zjištěna i v nedalekém rudním revíru Př́sečnice (Sejkora et al. 2019a,b).

\section{Poděkování}

Milou povinností autorů je poděkovat za poskytnutí fotografií P. Fuchsovi a B. Burešovi. Předložená práce vznikla za finanční podpory Ministerstva kultury ČR v rámci institucionálního financování dlouhodobého koncepčního rozvoje výzkumné organizace Národní muzeum (DKRVO 2019-2023/1.II.b, 00023272).

\section{Literatura}

Borisova VV, Voloshin AV, Kompanchenko AA, Selivanova EA, BazAy AV (2019) Namibite from Alakurtti Pegmatites, Kola Region. Geol Ore Depos 61(7): 647-653

Frost RL, Bahfenne RL, Čejka J, Sejkora J, Plášıl J, PalMER SJ (2010) Raman and infrared study of phyllosilicates containing heavy metals ( $\mathrm{Sb}, \mathrm{Bi})$ : bismutoferrite and chapmanite. J Raman Spectrosc 41: 814-819

Frost RL, Č́JKa J, SeJkora J, PlašIL J, Reddy BJ, KeefFE EC (2011) Raman spectroscopic study of a hydroxy-arsenate mineral containing bismuth - atelestite $\mathrm{Bi}_{2} \mathrm{O}(\mathrm{OH})\left(\mathrm{AsO}_{4}\right)$. Spectrochim Acta A 78: 494-496

Frost RL, Henry DA, Weiner ML, Martens W (2006) Raman spectroscopy of three polymorphs of $\mathrm{BiVO}_{4}$ : clinobisvanite, dreyerite and pucherite with comparison to $\left(\mathrm{VO}_{4}\right)^{3-}$ bearing minerals namibite, pottsite and schumacherite. J Raman Spectrosc 37: 722-732

HARDCASTLE FD, WACHS IE (1992) The molecular structure of bismuth oxide by Raman spectroscopy. J Solid State Chem 97: 319-331

GRICE JD (2002) A solution of the crystal structures of bismutite and beyerite. Can Mineral 40: 693-698

CHRT J (1962) Studie o perspektivách průzkumu nových fluoritových a fluorito-barytových ložisek v ČSSR. MS GP Praha

CHRT J (1973) Fluoritové a barytové suroviny Českého masívu 5120311 012. MS Geoindustria Praha

Chukanov NV, Vigasina MF (2020) Vibrational (Infrared and Raman) spectra of minerals and related compounds. Springer. 1-1376.

JONES GC, JACKSON B (1993) Infrared transmission spectra of carbonate minerals. Chapman and Hall London. 1-256.

Kolitsch U, GIESTER G (2000) The crystal structure of namibite, $\mathrm{Cu}(\mathrm{BiO})_{2} \mathrm{VO}_{4}(\mathrm{OH})$, and revision of its symmetry. Am Mineral 85: 1298-1301

LAUgIER J, Bochu B (2011) LMGP-Suite of Programs for the Interpretation of X-ray Experiments. http://www. ccp14.ac.uk/tutorial/lmgp, prístup duben 2011

LIENERT H (1971) Závěrečná zpráva Krušné hory - střed 5120311004 , surovina fluorit. MS Geoindustria Praha

MAYEROVÁ L, MAYER P (1967) Závěrečná zpráva, Krušné hory, prospekce 513311001 , surovina fluorit. MS archiv ČGS-Geofond, P 20608 
Mrázek Z, Veselovský F, HLoušek J, Moravcová H, Ondruš $\mathrm{P}(1994)$ Redefinition of namibite, $\mathrm{Cu}(\mathrm{BiO})_{2} \mathrm{VO}_{4} \mathrm{OH} . \mathrm{N}$ Jb Mineral, Mh 481-488

OndRuš P, VeselovskÝ F, HLoušek J, SkÁla R, VAVŘín I, FrÝDA J, ČEJKo J, GABAŠOVÁ A (1997) Secondary minerals of the Jáchymov (Joachimsthal) ore district. J Czech Geol Soc 42( 4): 3-76

Plášll J, Kampf AR, SeJKora J, Č́eJKa J, ŠKoda R, TVRdý J (2018) Horákite, a new hydrated bismuth uranyl-arsenate-phosphate mineral from Jáchymov (Czech Republic) with a unique uranyl-anion topology. J Geosci 63: $265-276$

Pouchou JL, PICHOIR F (1985) "PAP" ( $\varphi \rho Z)$ procedure for improved quantitative microanalysis. In: Microbeam Analysis (J. T. Armstrong, ed.). San Francisco Press, San Francisco, 104-106

Sejkora J, Pauliš P, Gramblička R, Malíková R, Pour O, DolničEK Z, Ulmanová J, VRTIŠKA L (2019a) Nově zjištěná Bi-Co-Ni-As-U-V mineralizace přísečnického rudního revíru v Krušných horách (Česká republika). Bull Mineral Petrolog 27(1): 1-37
SeJKora J, PAULIŠ P, GRAmbličKa R, Pour (2019b) Mottramit a Mn-oxidická mineralizace $z$ prísečnického rudního revíru v Krušných horách (Česká republika). Bull Mineral Petrolog 27(2): 374-382

Selvamani T, Raj BGS, Anandan S, Wu JJ, Ashokkumar M (2016) Synthesis of morphology-controlled bismutite for selective applications. Phys Chem Chem Phys 18: 7768-7779

ŠKÁCHA P, PLÁšIL J, HORÁK V (2019) Jáchymov mineralogická perla Krušnohoří. Academia, Praha. 1-688.

TAYLOR R, SUNDERS S, LOPATA VJ (1984) Structure, spectra, and stability of solid bismuth carbonates. Can J Chem 62: 2863-2873

Uehara S, ShIRose Y (2013) Namibite and hechtsbergite from the Nagatare mine, Fukuoka Prefecture, Japan. J Mineral Petrolog Sci 108(2): 105-110

von KnorRing O, SaHAma TG (1981) Namibite, a new copper - bismute - vanadian mineral from Namibia. Schweiz mineral petrogr Mitt 61: 7-12 